\title{
Ocurrence and caracterization of bovine abortion caused by Brucella abortus infection in southern Brazil
}

\author{
Ocurrencia y caracterización del aborto bovino causada por Brucella abortus \\ infección en el sur de Brasil
}

\author{
NAB Antoniassi ${ }^{a *}$, GD Juffo ${ }^{b}$, CA Pescador ${ }^{a}$, LG Corbellini $^{\mathrm{b}}$, L Sonne $^{\mathrm{b}}$, \\ MJP Gomes $^{b}$, L Nakazato ${ }^{a}$, D Driemeier ${ }^{b}$ \\ aFaculdade de Agronomia, Medicina Veterinária e Zootecnia, Universidade Federal de Mato Grosso, Cuiabá, Mato Grosso, Brasil. \\ ${ }^{\text {b}}$ Faculdade de Medicina Veterinária, Universidade Federal do Rio Grande do Sul, Porto Alegre, Rio Grande do Sul, Brasil.
}

\section{RESUMEN}

\begin{abstract}
La brucelosis causada por Brucella abortus es una enfermedad zoonótica contagiosa que causa abortos en las vacas, así como alteraciones articulares y reproductivos en los toros. En 469 fetos bovinos abortados analizados en un período de nueve años, nueve (1,92\%) se debieron a B. abortus infección. El diagnóstico se basó en los estudios de lesiones macroscópicas, histológicas, microbiológicas, serológicas, inmunohistoquímicas y hallazgos moleculares. La edad gestacional de los fetos osciló de 6 a 9 meses. Los principales hallazgos macroscópicos se caracterizaron por una descarga de pus en la cavidad nasal, tráquea y bronquios, y depósitos de fibrina pleural y pericárdico, además de los pulmones se han observado manchas blancas en el parénquima y las zonas rojas en los lóbulos apicales. En la región intercotiledonaria de tres placentas examinadas, hubo áreas enrojecidas intercaladas con zonas redondas de color amarillo-blanco bien definidos, con paredes engrosadas en la superficie de los cotiledones. Microscópicamente se observó bronconeumonía necrosupurativa, neumonía intersticial y placentitis necrosupurativa con áreas de vasculitis, la mineralización, y la trombosis. Brucella abortus fue aislado de los tejidos fetales de siete de los nueve casos investigados. La prueba de inmunohistoquímica fue positiva en cuatro casos, y la PCR amplifica el material genético de las bacterias en tres. La infección con B. abortus tiene que ser considerado como una posible causa de aborto en el ganado en el sur de Brasil.
\end{abstract}

Palabras clave: brucelosis, diagnóstico, ganado, fetos bovinos.

\section{SUMMARY}

Brucellosis caused by Brucella abortus infection is a contagious zoonotic disease that causes abortions in cows, as well as joint and reproductive alterations in bulls. This study reports that eight (1.92\%) out of a total of 469 aborted bovine fetuses analysed in a time frame of nine years were caused by $B$. abortus infection. The diagnosis was based on macroscopic, histological, microbiological, serological, immunohistochemical, and molecular findings. The gestational age of the fetuses studied ranged from 6 to 9 months. The main gross findings were purulent discharge from the nasal cavity, trachea and bronchi; pleural and pericardial fibrin deposits; and non-collapsed lungs with white spots in the parenchyma, and red areas in the apical lobes. Intercotyledonary areas of three placentas examined exhibited reddened areas, and the cotyledons exhibited well-defined, yellowish-white round areas with thickened walls on their surface. Microscopically, the most frequently observed lesions were necrosuppurative bronchopneumonia, interstitial pneumonia, and necrosuppurative placentitis with areas of vasculitis, mineralization, and thrombosis. Brucella abortus was isolated from fetal tissues of seven of the nine cases investigated. Immunohistochemical tests were positive in four cases, and PCR detected B. abortus genetic material in three cases. Infection by B. abortus should be considered a possible cause of abortion in cattle in southern Brazil.

Key words: brucellosis, diagnosis, cattle, bovine fetuses.

\section{INTRODUCTION}

Brucellosis is a contagious and generally chronic zoonosis from the mononuclear phagocyte system; it causes abortion in the last trimester of pregnancy as well as articular and reproductive changes in males (Paulin 2003). In bovines, this disease is caused by Brucella abortus, a Gram-negative, non-spore-forming, non-encapsulating rod or coccoid rod that is preferentially intracellular (Paulin

Accepted: 27.08.2015.

* Av. Fernando Correa da Costa, 2367, Cuiabá, MT, 78060-900, Brasil; naassi@gmail.com
2003). Brucellosis has considerable socioeconomic importance owing to its implications for public health, and also because of economic losses caused by reproduction problems or imposition of sanitary barriers (Brasil 2001, Paulin 2003). Brucellosis is reported to have low prevalence in cattle herds worldwide (Godfroid et al 2004, Schlafer et al 2007). However, in some countries where brucellosis is endemic and not controlled, prevalence may vary between 20\% and 30\% (Godfroid et al 2004). In Brazil, the endemic status of this disease is stable, with higher prevalence in regions where animal density is higher (Brasil 2001).

Environmental contamination with membranes and fetal fluids as well as vaginal discharges of infected 
females is the main infection source of transmission for bovines (Godfroid et al 2004, Schlafer et al 2007). In pregnant females, $B$. abortus reaches the endometrium and the placenta through the blood during bacteremia, and reproduces in trophoblastic cells (Meador and Deyoe 1989), causing necrotic pancreatitis which eventually leads to abortion (Paulin 2003, Godfroid et al 2004, Schlafer et al 2007). Fetal alterations, when present, may include bronchopneumonia (Lopez et al 1984, Schlafer et al 2007), meningitis (Hong et al 1991), vasculitis (Schlafer et al 2007), thrombosis in lymph and blood vessels (Lopez et al 1984), and formation of giant cell granulomas in several organs (Schlafer et al 2007).

The diagnosis of abortion by B. abortus may be based on the presence of macroscopic and histological lesions, bacterial isolation (mainly from abomasal contents), immunofluorescence, immunohistochemistry (Schlafer et al 2007), or polymerase chain reaction (PCR) (Cortez et al 2006).

The objectives of the present study were to estimate the occurrence of abortions caused by B. abortus in bovines in southern Brazil, and to characterize macroscopic, histopathological, bacteriological, immunohistochemical, and PCR findings in the aborted fetuses.

\section{MATERIAL AND METHODS}

In a period of eight years, 469 aborted bovine fetuses were submitted for diagnosis to the Veterinary Pathology Service (SPV), Federal University of Rio Grande do Sul (UFRGS), Brazil. All fetuses were from southern Brazil. Abortion was defined as spontaneous termination of pregnancy between 42 and 260 days. Fetuses were necropsied, and age was estimated based on crown-rump length (Barr et al 1990). Tissue fragments from fetuses and placentas, when available, were collected and fixed in $10 \%$ buffered formalin, processed for histological examination, and stained with hematoxylin and eosin following standard procedures. Kidney sections were analyzed by direct immunofluorescence to detect Leptospira spp. using multivalent fluorescent antibody conjugates at a dilution of 1:20 (Miller et al 1989). Liver and lung specimens and abomasal contents were collected for aerobic bacterial culture and isolation of B. abortus. Microaerophilic growth was attained by culture in blood agar supplemented with $7 \%$ sheep blood under incubation for 48 h. Brucella abortus was isolated using Brucella Agar supplemented with specific antimicrobial agents. The genus was identified based on the characteristics of culture morphology, biochemistry and color (Bathke 1988).

Immunohistochemical analysis to detect B. abortus was carried out whenever fetuses exhibited signs of pneumonia, meningitis and placentitis. The polyclonal antibodies used for immunohistochemical assays were produced at SPV-UFRGS by inoculation of the antigen in rabbits. To this end, a $1 \mathrm{~mL}$ dose of live Brucella abortus (B19) commercial vaccine was subcutaneously administered in rabbits. Forty days later, sera were collected, and the IgG fraction was purified using an affinity chromatography column (GE Healthcare). For immunohistochemistry, the primary antibody was diluted 1:500, added to the specimens, and incubated for $60 \mathrm{~min}$ at $37^{\circ} \mathrm{C}$. A proteinase $\mathrm{K}$ solution (Dako) was used to retrieve the antigen (10 $\mathrm{min}$ ), and non-specific nuclear staining was blocked by using $5 \%$ (w/v) nonfat dry Milk (Molico ${ }^{\mathrm{TM}}$ ) (15 min). Samples were incubated with a biotinylated secondary antibody for $15 \mathrm{~min}$ at room temperature. An avidin-phosphatase conjugate solution (LSAB + AP kit) (Dakocytomation) was added to the samples, which were then incubated for 15 min at room temperature. Bio Red (Biopath) was used as the chromogen; samples were incubated with it for 5 to 10 minutes, and counterstained with hematoxylin for 1 min. Thymus and central nervous system fragments were subjected to immunohistochemical analysis for bovine viral diarrhea (BVD) using the anti-BVDV monoclonal antibody (15C5 Syracuse, USA) as described by Schmitz (2006).

PCR was used to detect B. abortus in samples of fetuses with lesions indicative of infection by this bacterium, or in samples from which $B$. abortus isolation was successful. DNA was extracted from $25 \mathrm{mg}$ samples from $10 \mathrm{~mm}$ paraffin-embedded tissue specimens (Garmatz et al 2004). PCR was performed using specific primers (5' -GAC GAA CGG AAT TTT TCC AAT CCC-3' and 5' - TGC CGA TCA CTT AAG GGC CTT CAT TGC CAG-3') as described by Baily et al. (1992). The PCR protocol used consisted of an initial denaturation step at $94{ }^{\circ} \mathrm{C}$ for $5 \mathrm{~min}, 30$ cycles of denaturation $\left(94^{\circ} \mathrm{C}, 30 \mathrm{~s}\right)$, annealing $\left(53^{\circ} \mathrm{C}, 30 \mathrm{~s}\right)$ and extension $\left(72{ }^{\circ} \mathrm{C}, 5 \mathrm{~s}\right)$, and a final extension step at $72{ }^{\circ} \mathrm{C}$ for $5 \mathrm{~min}$. The reaction amplified $498 \mathrm{bp}$ fragments, which were electrophoresed in $1 \%$ agarose gels. The gels were electrophoresed in TBE $0.5 \mathrm{X}$ buffer (0.045 M TRISBorate and $1 \mathrm{mM}$ EDTA pH 8.0). The amplified fragments were observed under UV light, and then photographed for subsequent examination. A suspension of the B19 vaccine was used as a positive control in PCR reactions; negative controls consisted of PCR reactions without any DNA, but with ultrapure water instead.

Abortion was defined as caused by B. abortus infection when fetuses exhibited lesions compatible with those caused by this pathogen, and results of at least one of the assays carried out to detect this agent (bacterial isolation, immunohistochemistry, and PCR) were positive.

\section{RESULTS}

Macroscopic, histological, microbiological, serological, immunohistochemical, and molecular findings revealed that, of the 469 aborted fetuses examined in a period of eight years, nine (1.96\%) were consequent to $B$. abortus infection (Table 1). Gestational age of aborted fetuses varied from 6 to 9 months. All fetuses were from nine farms located in southern Brazil. The history of previous vaccination 
Table 1. Microaerophilic growth (isolation), immunohistochemistry, and PCR results of Brucella abortus in aborted bovine fetuses. Resultados del crecimiento en condiciones de microaerofilia, inmunohistoquímica y PCR para Brucella abortus en fetos bovinos abortados.

\begin{tabular}{|c|c|c|c|c|c|c|c|c|c|c|}
\hline \multirow{2}{*}{ Fetuses } & \multicolumn{3}{|c|}{ Isolation } & \multicolumn{3}{|c|}{ Immunohistochemistry } & \multicolumn{4}{|c|}{ PCR } \\
\hline & Lung & Liver & $\mathrm{AC}$ & CNS & Lung & Placenta & Lung & Placenta & Liver, kidney, SM & CNS \\
\hline 1 & $\mathrm{~N}$ & $\mathrm{~N}$ & $\mathrm{P}$ & $\mathrm{NC}$ & $\mathrm{N}$ & $\mathrm{NC}$ & $\mathrm{N}$ & $\mathrm{NC}$ & $\mathrm{NC}$ & $\mathrm{NC}$ \\
\hline 2 & $\mathrm{~N}$ & $\mathrm{~N}$ & $\mathrm{P}$ & $\mathrm{NC}$ & $\mathrm{P}$ & $\mathrm{NC}$ & $\mathrm{N}$ & $\mathrm{NC}$ & $\mathrm{NC}$ & $\mathrm{NC}$ \\
\hline 3 & $\mathrm{~N}$ & $\mathrm{~N}$ & $\mathrm{P}$ & $\mathrm{NC}$ & $\mathrm{N}$ & $\mathrm{NC}$ & $\mathrm{N}$ & $\mathrm{NC}$ & $\mathrm{NC}$ & $\mathrm{NC}$ \\
\hline 4 & $\mathrm{~N}$ & $\mathrm{~N}$ & $\mathrm{P}$ & $\mathrm{NC}$ & $P$ & $\mathrm{NC}$ & $\mathrm{N}$ & $\mathrm{NC}$ & $\mathrm{NC}$ & $\mathrm{NC}$ \\
\hline 5 & $\mathrm{~N}$ & $\mathrm{~N}$ & $\mathrm{P}$ & $\mathrm{NC}$ & $\mathrm{N}$ & $\mathrm{NC}$ & $\mathrm{P}$ & $\mathrm{NC}$ & $\mathrm{P}$ & $\mathrm{NC}$ \\
\hline 6 & $\mathrm{~N}$ & $\mathrm{~N}$ & $\mathrm{~N}$ & $\mathrm{NC}$ & $\mathrm{N}$ & $\mathrm{N}$ & $\mathrm{N}$ & $P$ & $\mathrm{NC}$ & $\mathrm{NC}$ \\
\hline 7 & $\mathrm{P}$ & $\mathrm{P}$ & $\mathrm{N}$ & $\mathrm{P}$ & $\mathrm{P}$ & $P$ & $P$ & $P$ & $\mathrm{NC}$ & $\mathrm{P}$ \\
\hline 8 & $\mathrm{~N}$ & $\mathrm{~N}$ & $\mathrm{~N}$ & $\mathrm{NC}$ & $\mathrm{P}$ & $\mathrm{P}$ & $\mathrm{N}$ & $\mathrm{N}$ & $\mathrm{NC}$ & $\mathrm{NC}$ \\
\hline 9 & $P$ & $\mathrm{~N}$ & $\mathrm{P}$ & $\mathrm{NC}$ & $\mathrm{N}$ & $\mathrm{N}$ & $\mathrm{N}$ & $\mathrm{N}$ & $\mathrm{NC}$ & $\mathrm{NC}$ \\
\hline
\end{tabular}

N: Negative; P: Positive; AC: Abomasal content; CNS: Central nervous system; SM: Skeletal muscle; NC: Not conducted. N: Negativo; P: Positivo; AC: Contenido del abomaso; CNS: Sistema nervioso central; SM: Músculo esquelético; NC: No realizado.

against brucellosis was analysed, and revealed that: (i) in three farms, vaccination was applied appropriately; (ii) in one farm, the age of animals at vaccination was unknown; (iii) in two farms, no vaccination protocol was followed; and (iv) in three farms, vaccination was not mentioned in the paperwork that accompanied the fetuses.

Macroscopic lesions were observed in six of the nine fetuses identified as positive for $B$. abortus infection (Fetuses 2, 4, 5, 7, 8, and 9). These lesions included mucopurulent nasal discharge (also present in the tracheal lumen and bronchi of fetus 8 ) as well as fibrin deposition on pleural surfaces (Fetuses 7, 8, and 9) and pericardium (Fetus 7) (figure 1A). All fetuses exhibited white spots in the lung parenchyma (figure 1B). Fetuses 1 and 3 exhibited non-collapsed lungs, and reddish areas were seen in the apical lobes of Fetus 9. The liver of Fetus 4 exhibited white areas interspersed with red areas. The liver of Fetus 5 was enlarged and presented a red surface. Hemorrhagic foci were observed on the sublingual surface of the tongue of Fetus 1, in the kidneys of Fetus 2, on the skin and in the spleen of Fetus 4, and in the skeletal muscle tissue of the hindlimbs of Fetus 9. The placentas of only three fetuses $(6,7$, and 9$)$ were submitted for analysis. The alterations observed in these placentas included red areas in the intercotyledonary regions (Fetuses 6 and 7), well-outlined yellowish-white circular areas (Fetus 7) (figure 1C), and thickened wall with intensely red, poorly defined areas (fetus 9).

Microscopic changes were present in seven fetuses $(1,2,3,4,5,7$, and 9) and included various degrees of subacute fibrinopurulent pleuritis (Fetuses 1, 2, 3, 4, 5, and 7), severe diffuse fibrinopurulent pericarditis (Fetus 7), subacute necrosuppurative bronchopneumonia (Fetuses 4, 5, and 9) (figure 2A), fibrinopurulent bronchopneumonia (Fetus 8), and subacute mononuclear interstitial pneumonia (Fetuses 1 and 2). Mononuclear vasculitis was diagnosed in the lungs (Fetuses 3, 4, and 5) and skeletal muscle (Fetus
4). Mononuclear hepatitis was present in Fetuses 3, 4, and 9 (in the latter, it was accompanied by necrotic foci). Severe multifocal mononuclear meningitis accompanied by multifocal perivascular cuffing was detected in the brain of Fetus 7 (figure 2B). In Fetus 8, the thymus exhibited a diffuse mononuclear inflammatory infiltrate which was more pronounced in trabeculae, and fibrin thrombi. Mild focal mononuclear myositis and multifocal areas with marked hyaline degeneration were detected in the skeletal muscle of Fetus 9. Focal hemorrhagic infarction was observed in the spleen of Fetus 3. Mononuclear and polymorphonuclear inflammatory cells were observed in vessels of organs such as brain and lungs as well as in skeletal muscles of all fetuses, except in Fetuses 6 and 8. Congestion areas were noticed in kidneys, liver, spleen (Fetus 8) and thymus (Fetuses 8 and 9). Placental lesions included subacute mononuclear placentitis accompanied by necrosuppurative vasculitis (figure 2C), areas of mineralization, thrombosis, presence of structures compatible with bacteria inside of trophoblasts (Fetus 6), mild suppurative perivasculitis (Fetus 7), and moderate necrossupurative placentitis (Fetus 9).

Brucella abortus was isolated from seven fetuses $(1,2,3$, $4,5,7$, and 9). This bacterium was isolated from abomasal contents in five fetuses (Fetuses 1, 2, 3, 4, and 5), from lung and liver fragments in one fetus (Fetus 7), and from abomasal contents and lung fragments in one fetus (Fetus 9). Positive immunohistochemical staining for B. abortus was observed in Fetuses 2, 4, 7, and 8. Bacterial antigens were detected inside mononuclear inflammatory cells in lung alveoli and cell debris in Fetus 2, and in necrotic foci in the lungs of Fetuses 4, 7, and 8 (figure 2A). Positive staining was also observed in mononuclear inflammatory cells and in the lumen of blood vessels of the meninges (Fetus 7) and placenta (Fetuses 7 and 8) (figure 2B and 2C). PCR detected Brucella abortus genetic material in tissues of Fetuses 5 and 7, and in the placenta of Fetus 


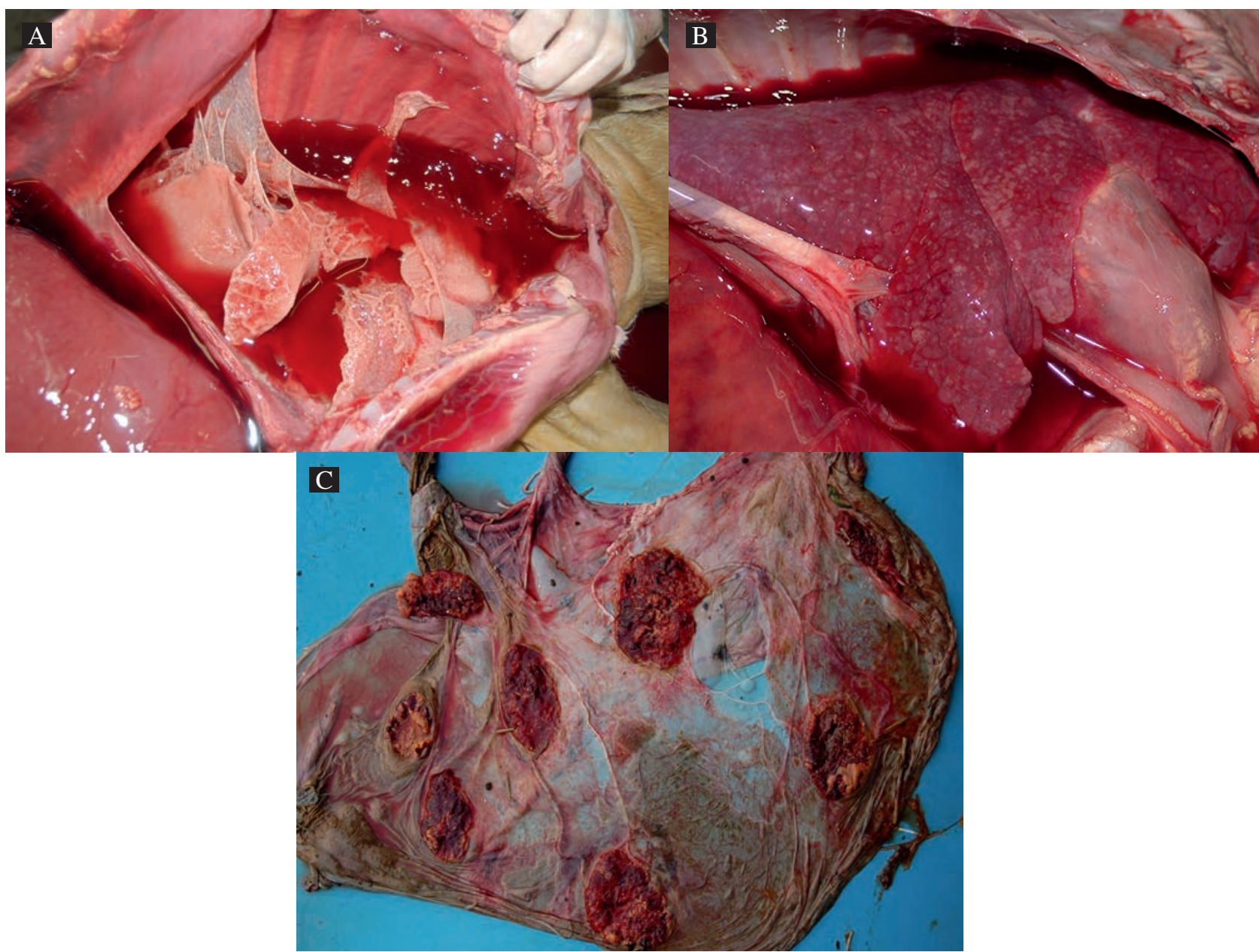

Figure 1. Aborted bovine fetuses infected with Brucella abortus. A. Intense fibrin deposition on the pleural and pericardial surfaces, and purulent fluid in the thoracic cavity. B. White spots in the lung parenchyma measuring between $0.1 \mathrm{~mm}$ and $0.5 \mathrm{~mm}$ in diameter, and purulent fluid in the thoracic cavity. C. Placenta exhibiting red areas in the intercotyledonary regions, and well-defined yellowishwhite round areas on the cotyledonary surface.

Fetos bovinos abortados infectados con Brucella abortus. A. Intenso depósito de fibrina en la superficie pleural y pericardico, y líquido supurativo en la cavidad torácica. B. Manchas blancas en el parénquima pulmonar entre $0,1 \mathrm{~mm}$ y $0,5 \mathrm{~mm}$ de diámetro, y fluido supurativa en la cavidad torácica. C. Placenta mostrando zonas rojas de la región intercotiledonaria y zonas bien delimitadas circunscritas amarillo pálido en la superficie cotiledonaria.

6. Direct immunofluorescence for Leptospira spp. and immunohistochemistry for bovine viral diarrhea (BVD) yielded negative results". Table 1 shows a summary of the results of microbiological, immunohistochemical, and PCR analyses.

\section{DISCUSSION}

The prevalence of $B$. abortus infection in aborted bovine fetuses analysed at SPV-UFRGS in a period of eight years was $1.92 \%$. Data regarding the prevalence of this pathogen in aborted fetuses are scarce in the literature, and the variation in published results can be a result of the different diagnostic methods used across studies. In Argentina, Campero et al (2003) diagnosed infection by B. abortus in $7.9 \%$ of 354 fetuses. In Brazil, Cortez et al
(2006) detected the presence of Brucella spp. DNA in $13.7 \%$ of 124 samples analyzed using PCR. Likewise, $B$. abortus was isolated from $70(5.56 \%)$ of 1,259 aborted fetuses using bacteriological methods (Genovez et al 2006).

In the present study, gestational age of fetuses varied between 6 and 9 months. This finding confirms previous reports on the occurrence of abortion at the end of pregnancy in bovines infected with B. abortus (Godfroid et al 2004, Schlafer et al 2007). Other cases of abortion caused by $B$. abortus had been reported in all farms where the fetuses analysed here had come from, showing that these were not isolated events, and that the cases investigated here may represent only a small fraction of the actual problem in a large-scale production system.

The diagnosis of $B$. abortus as the causative agent of abortions was based on macroscopic and histological 


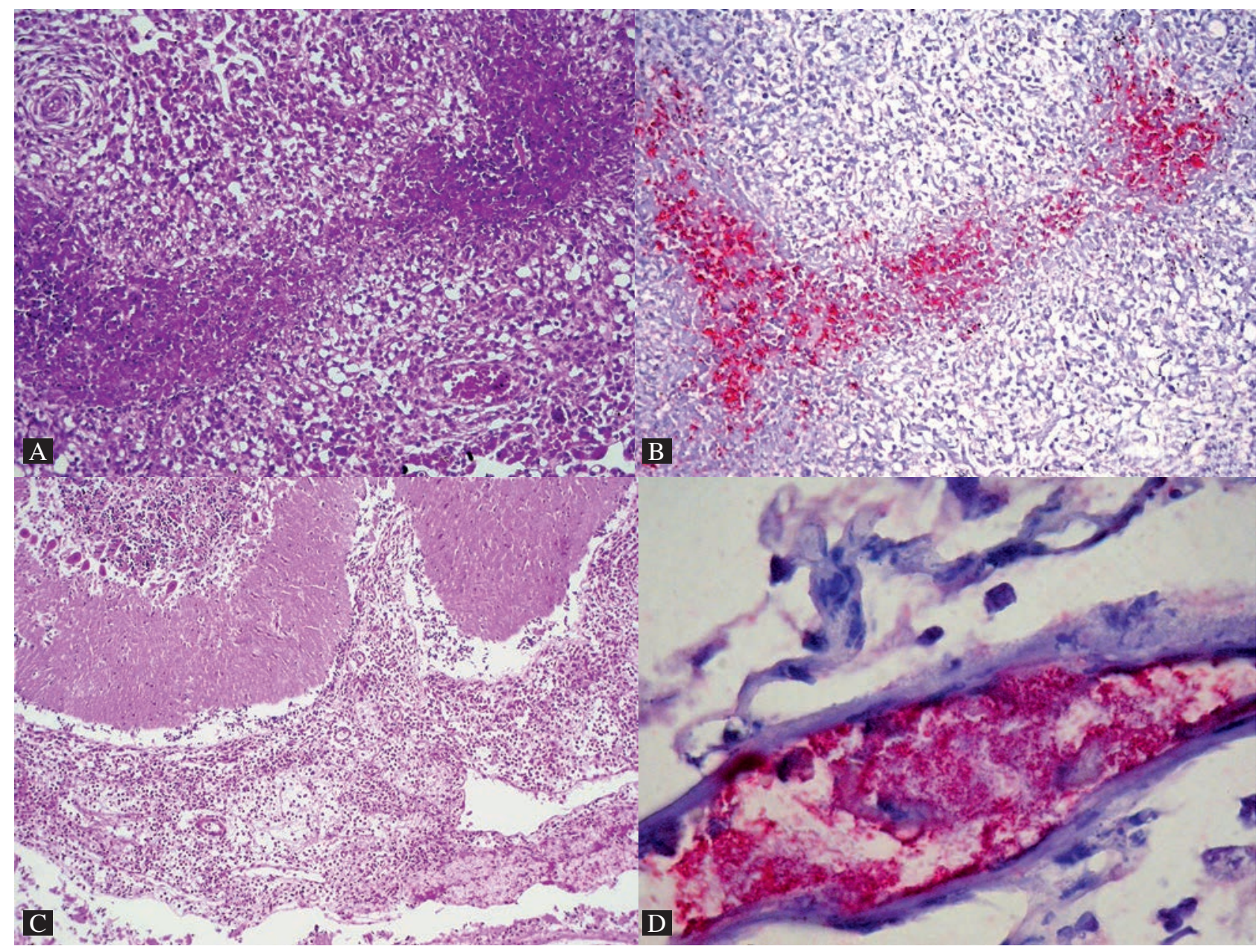

Figure 2. Histology sections from aborted bovine fetuses infected with Brucella abortus. A. Lung, acute multifocal necrosuppurative bronchopneumonia (100x magnification, HE). B. Lung, red immunohistochemical staining of $B$. abortus bacterial antigens in necrotic foci (100x magnification). C. Cerebelum, focally extensive granulomatous meningitis (100x magnification). D. Placenta, red immunohistochemical staining of $B$. abortus bacterial antigens in blood vessel (400x magnification, HE).

Secciones histológicas de bovinos abortados infectados con Brucella abortus. A. Pulmón, bronconeumonía multifocal aguda necrosupurativa (aumento de 100x, HE). B. Pulmón, mediante técnicas de inmunohistoquímica con la marca roja de antígenos bacterianos de $B$. abortus en zonas necróticas (aumento de 10x). C. Cerebelo, meningitis granulomatosa focalmente amplio (aumento de 10x, HE). D. Placenta, mediante técnicas de inmunohistoquímica con la marca roja de antígenos bacterianos de $B$. abortus en vasos sanguíneos.

findings combined with the isolation of the agent in fetal tissues, as well as on immunohistochemical and PCR analyses. The macroscopic and microscopic lesions reported here are compatible with those previously described for abortions caused by B. abortus (Lopez et al 1984, Meador et al 1986, Hong et al 1991, Godfroid et al 2004, Schlafer et al 2007), and are linked to the infection of the fetus by aspiration of contaminated amniotic fluid (Lopez et al 1984). However, in some cases, abortion may be a consequence of placentitis caused by brucellosis with or without aspiration of amniotic fluid, and the fetus may not exhibit typical lesions (Lopez et al 1984). In such cases, analysis of the placenta is essential for an accurate diagnosis. No alterations were observed in Fetus 6; however, its placenta exhibited not only lesions typically seen in abortion caused by $B$. abortus, but also had genetic material from this bacterium amplified by PCR, proving that the pathogen was indeed present.

Brucella abortus was not isolated from tissues of Fetuses 6 and 8 . It has been reported that, even when histological findings are present, the pathogen may not be isolated from fetal tissues owing to inappropriate isolation procedures; additionally, these lesions can be caused by bacteria other than B. abortus (Lopez et al 1984). In these two fetuses, diagnosis was confirmed by PCR of placental tissues (fetus 6) and immunohistochemical analysis of lung and placental tissues (Fetus 8).

Several authors have reported an association between B. abortus infection and macroscopic alterations such as subcutaneous and skeletal muscle edema, as well as 
Table 2. Description of macroscopic and microscopic alterations observed in placentas and aborted fetuses with infection by Brucella abortus, examined at SPV-UFRGS.

Descripción de alteraciones macroscópicas y microscópicas observadas en placentas y fetos abortados infectados por Brucella abortus, examinados en SPV-UFRGS.

\begin{tabular}{cc}
\hline Fetus & Macroscopic alterations \\
\hline $1 \quad$ Lung: not collapsed.
\end{tabular}

1 Lung: not collapsed.

2 Lung: diffuse white spots on the surface and parenchyma.

3 Lung: not collapsed. Brain: Moderate congestion.

4 Lung: diffuse white spots on the surface and parenchyma. Skin: hemorrhagic areas. Liver: red areas interspersed with whitish areas. Spleen: diffuse bruising.

5 Lung: whitish areas of firm consistency interspersed with reddish areas.

6 Placenta: reddened areas on intercotyledonary surface.

7 Pericardium and pleura: marked fibrin deposition. Placenta: reddened areas on intercotyledonary surface with yellowish-white circumscribed areas.

8 Nasal and tracheal mucopurulent secretion. Pleura: mild fibrin deposition. Lung: white spots randomly distributed throughout the surface and parenchyma.

9 Lung: red areas in the apical lobes and white dots on the surface and parenchyma. Skeletal muscles of the right hind limb: hemorrhagic focus; Placenta: thick, intensely red.

serohemorrhagic lesions in the thoracic cavity (Hong et al 1991, Godfroid et al 2004, Schlafer et al 2007). However, these alterations are observed in essentially all aborted fetuses, independent of cause of abortion, which indicates that they may be a consequence of post mortem processes. The fact that fetuses 1 and 3 exhibited non-collapsed lungs suggests increased fetal breathing owing to anoxia caused by necrotic placentitis. The hemorrhagic foci observed in
Microscopic alterations

Lung: marked, diffuse, fibrinpurulent pleuritis. Interstitial mononuclear subacute pneumonia with the presence of fibrin; mononuclear inflammatory cells within the vessels. CNS: mononuclear inflammatory cells within the vessels.

Lung: moderate subacute fibrinpurulent pleuritis; subacute mononuclear interstitial pneumonia with fibrin; cellular debris within bronchi. CNS: mononuclear inflammatory cells within the vessels.

Lung: moderate multifocal fibrinpurulent pleuritis, severe multifocal mononuclear vasculitis; Liver: mild focal mononuclear hepatitis. CNS: mononuclear inflammatory cells within the vessels; moderate congestion. Spleen: acute, extensive, focal hemorrhagic infarction. Skeletal muscle: polymorphonuclear inflammatory cells within the vessels.

Lung: mild multifocal subacute fibrinpurulent pleuritis; severe multifocal subacute necrosuppurative bronchopneumonia, mild multifocal mononuclear vasculitis; mononuclear inflammatory cells within the vessels. Liver: moderate, focal, mononuclear hepatitis. Skeletal muscle: mild multifocal mononuclear vasculitis. CNS: inflammatory mononuclear cells in blood vessels.

Lung: moderate diffuse subacute fibrinpurulent pleuritis; marked diffuse necro-suppurative bronchopneumonia; acute to subacute multifocal lymphocytic vasculitis; large amount of mononuclear inflammatory cells inside vessels. CNS: mononuclear inflammatory cells within the vessels.

Placenta: marked diffuse subacute mononuclear placentitis with areas of calcification and necro-moderate multifocal suppurative vasculitis; presence of similar structures bacteria inside the cells. trophoblast; thrombi in vessels.

Lung: marked diffuse purulent pleuritis; Presence of inflammatory cells within the vessels. CNS: multifocal perivascular cuffing; moderate extensive focal purulent meningitis. Placenta: mild purulent perivasculitis. Heart: marked diffuse fibrinpurulent pericarditis.

Lung: marked fibrinpurulent bronchopneumonia and fibrin thrombi. Liver: marked diffuse congestion. Rim: severe congestion and diffuse hemorrhage. Thymus: diffuse acute mononuclear inflammatory infiltrate in trabeculae, fibrin, and moderate diffuse congestion. Spleen: marked diffuse congestion.

Lung: marked diffuse necrosuppurative bronchopneumonia. Placenta: moderate necrosuppurative placentitis. Liver: moderate multifocal hepatitis and focus of necrosis. CNS: polymorphonuclear cells inside vessels and moderate congestion. Skeletal muscle: mild focal polymorphonuclear infiltrate and multifocal areas of severe hyaline degeneration. Thymus: Moderate congestion. various organs were also attributed to blood stasis owing to placental lesions.

Mononuclear and polymorphonuclear inflammatory cells observed in blood vessels of various tissues are commonly diagnosed in abortions caused by infections, and were detected in almost all fetuses examined here, except for fetuses 6 and 8 . These cells may be linked to a cell response of the fetus against infection. 
Positive immunohistochemical staining for Brucella abortus in organs such as lung, and the meninges placenta was observed (fetal 2, 4, 7 and 8). Antigen labeling in the cytoplasm of chorionic epithelial cells and of phagocytic cells demonstrates the intracellular location of Brucella spp. in these host cells, although positive labeling is also observed inside vessels and cell debris of necrotic foci (Meador et al 1986, Perez et al 1998). Immunohistochemical assays are highly specific to detect $B$. abortus antigens, although the sensitivity of this technique is low (Meador et al 1986, Perez et al 1998). Negative staining, even in cases in which bacterial isolation from tissues is successful, may be a result of low concentration of microorganisms in these samples. A minimum number of colony forming units, or at least accumulation of microorganisms on the tissue section, are necessary for the chromogen to reveal the pathogen (Meador et al 1986).

Brucella abortus genetic material was amplified by PCR in samples of placenta and/or fetal tissues in three cases only. In spite of the high sensitivity of the technique, some factors may affect results, such as sample preservation and storage conditions. Also, false negative results may be due to the presence of genetic material below the detection limit of the PCR strategy used, or to prolonged sample storage in formaldehyde, which can damage DNA. Accordingly, PCR protocols may be used as a complementary diagnostic tool, since the concomitant use of several diagnostic methods increases the odds of effectively detecting a pathogen (Silva et al 2009). Immunohistochemistry and PCR may be useful for the diagnosis of $B$. abortus when bovine fetal tissues are not available for bacterial cultivation, especially when placental tissues are available, since the concentration of contaminating microorganisms in the placenta is higher. However, observation of histological alterations both in the fetus and in the placenta, in addition to detection of the presence of $B$. abortus by immunhohistochemistry, bacterial isolation, or PCR, is essential for the diagnosis of brucellosis abortion.

\section{ACKNOWLEDGEMENTS}

The authors are grateful to Professors Marisa Cardoso, PhD, (UFRGS) and Marisa da Costa, PhD, (UFRGS) for the bacteriological assays, and to Coordenação de Aperfeiçoamento de Pessoal de Nível Superior (CAPES) and Conselho Nacional de Desenvolvimento Científico e Tecnológico $(\mathrm{CNPq})$ for financial support.

\section{REFERENCES}

Baily GG, JB Krahn, BS Drasar, NG Stoker. 1992. Detection of Brucella melitensis and Brucella abortus by DNA amplification. J Trop Med Hyg 95, 271-275.
Barr CB, ML Anderson, PC Blanchard, BM Daft, H Kinde, PA Conrad. 1990. Bovine fetal encephalitis and myocarditis associated with protozoal infections. Vet Pathol 27, 354-361.

Brasil. 2001. Regulamento Técnico do Programa Nacional de Controle da Brucelose e da Tuberculose Animal Departamento de Defesa Animal, Secretaria de Defesa Agropecuária, Ministério da Agricultura e do Abastecimento, Brasília, Brasil.

Bathke W. Brucellosis. 1988. Doenças infecciosas em animais domésticos: doenças causadas por vírus, clamídias, ricketticiose, micoplasmose. Roca, São Paulo, Brazil.

Campero CM, DP Moore, AC Odeon, AL Cipolla, E Odriozola. 2003. Aetiology of bovine abortion in Argentina. Vet Res Commun 27, 259-269.

Cortez A, AMG Castro, MB Heinemann, RC Soares, RC Leite, E Scarcelli, ME Genovez, AA Alfieri, LJ Richtzenhain. 2006. Detecção de ácidos nucléicos de Brucella spp, Leptospira spp, herpesvirus bovino e vírus da diarréia viral bovina, em fetos bovinos abortados e em animais mortos no perinatal. Arq Bras Med Vet Zootec 58, 1226-1228.

Garmatz SL, LF Irigoyen, RR Rech, CC Brown, J Zhang, CSL Barros. 2004. Febre catarral maligna em bovinos no Rio Grande do Sul: transmissão experimental para bovinos e caracterização do agente etiológico. Pesq Vet Bras 24, 93-106.

Genovez ME, E Scarcelli, MV Cardoso, RM Piatti, FR Campos, SR Teixeira, V Castro, TB Gotti, CA Batista. 2006. Main bacterial agents as cause of abortion in bovines in Brazil. XXIV World Buiatrics Congress, Nice, France.

Godfroid J, PP Bosman, S Herr, GC Bishop. 2004. Bovine brucellosis. In: Coetzer JAW, Tustin RC (eds). Infectious Diseases of Livestock. Vol 3. $2^{\text {nd }}$ ed. Oxford University Press, Cape Town, South Africa, Pp 1510-1527.

Hong CB, JM Donahue, RC Giles, JKB Poonacha, PA Tuttle, NF Cheville. 1991. Brucella abortus-associated meningitis in aborted bovine fetuses. Vet Pathol 28, 492-496.

Lopez A, F Hitos, A Perez, RR Navarro-Fierro. 1984. Lung lesions in bovine fetuses aborted by Brucella abortus. Can J Comp Med 48, 275-277.

Meador VP, LB Tabatabai, WA Hagemoser, BL Deyoe. 1986. Identification of Brucella abortus in formalin-fixed, paraffin-embedded tissues of cows, goats and mice with an avidin-biotin-peroxidase complex immunoenzymatic staining technique. Am J Vet Res 47, 2147-2150.

Meador VP, BL Deyoe. 1989. Intracellular localization of Brucella abortus in bovine placenta Vet Pathol 26, 513-515.

Miller DA, MA Wilson, CA Kirkbride. 1989. Evaluation of multivalent leptospira fluorescent antibody conjugates for general diagnostic use. J Vet Diagn Invest 1, 146-149.

Paulin LM. 2003. Brucelose. Arq Inst Biol 70, 239-249.

Perez J, M Quezada, J Lopez, O Casquet, MA Sierra, JM Mulas. 1998. Immunohistochemical detection of Brucella abortus antigens in tissues from aborted bovine fetuses using a commercially available polyclonal antibody. J Vet Diagn Invest 10, 17-21.

Schlafer DH, RB Miller. 2007. Female genital system. In: Maxie MG, Jubb KV, Kennedy PC, Palmer N (eds). Jubb, Kennedy and Palmer's Pathology of Domestic Animals. Vol. 3. $5^{\text {th }}$ ed. Saunders Elsevier, Philadelphia, USA, Pp 429-564.

Schmitz M. 2006. Caracterização patológica e imunoistoquímica da infecção pelo vírus da diarréia viral bovina. MSc thesis, Faculdade de Medicina Veterinária, Universidade Federal do Rio Grande do Sul, Porto Alegre, Brazil.

Silva TMA, RLG Oliveira, JPS Mol, MN Xavier, TA Paixão, A Cortez, MB Heinemann, LJ Richtzenhain, AP Lage, RL Santos. 2009. Etiologic diagnosis of bovine infectious abortion by PCR. Cienc Rural 39, 2563-2570. 
